\title{
First record of late Valanginian ammonites from the Mecsek Mountains (Hungary), and their importance for regional stratigraphy
}

\author{
László Bujtor ${ }^{1}[$ (D) Gergő Gőgös²
}

Received: 28 July 2020 / Accepted: 21 April 2021 / Published online: 2 June 2021

(c) The Author(s) 2021

\begin{abstract}
A fairly preserved ammonite of Early Cretaceous age from the Mecsek Mountains, southern Hungary is described. Tescheniceras subpachydicranum is the first record of late Valanginian ammonites from the Mecsek tectonic zone from a previously unknown locality indicating the uppermost Valanginian Criosarasinella furcillata Zone. This is the first ammonite-supported evidence for the presence of upper Valanginian strata in the Mecsek Mountains that stretches the time-span of the continuous basinal sedimentation from the beginning of the Berriasian till the Valanginian. The new finding raises the possibility for the presence of the Hauterivian strata too, which was never recognised by ammonites.
\end{abstract}

Keywords Tescheniceras · Tisza Mega-unit · Upper Valanginian · Criosarasinella furcillata Zone

\section{Introduction}

The Early Cretaceous faunas of the Mecsek Mountains are well known since the beginning of the twentieth century, but restricted to a handful outcrops that are situated in the eastern Mecsek Mountains. Hofmann (1907) recognised first the sedimentary strata at Kisújbánya (Fig. 1) and reported a rich, poorly preserved littoral-sublittoral fauna dominated by gastropods and bivalves (Hofmann and Vadász 1912). According to Hofmann, this assemblage represents the 'middle Neocomian' that later Vadász $(1914,1935)$ referred as Hauterivian age. The locality became the 'reference section' for the lower Cretaceous sedimentary succession that provided a poorly preserved but rich fauna (63 species were reported). Horvath (1968) analysed the fauna of the accompanying Marl beds and reported Holcostephanus (Astieria) cf. astierianus, Holcophylloceras calypso,

Handling Editor: Christian Klug.

László Bujtor

lbujtor@gamma.ttk.pte.hu

Gergő Gőgös

gergg0586@gmail.com

1 Department of Geology and Meteorology, Institute of Geography and Earth Sciences, University of Pécs, 6 Ifjúság útja, 7624 Pécs, Hungary

2 Faculty of Sciences, University of Pécs, Pécs, Hungary
Ptychophylloceras semisulcatum, Lyticoceras regale [=Endemoceras regale; Klein 2005: 350], Acanthodiscus hystricoides [=Fuhriella hystricoides; Klein 2005: 274], and Acanthoceras hoheneggeri [= Fuhriella hoheneggeri; Bujtor 2013: 7]. According to Horváth (1968), this assemblage represents the upper Valanginian, while the upper part of the Kisújbánya section belongs to the Hauterivian. Bujtor (1993) visited the locality, made new collection and concluded that the conglomerate bed that provided the rich littoral fauna is a turbidite bed in the hemipelagic Marl sequence and represents the early Valanginian (Thurmanniceras pertransiens Zone). Fülöp (in Hetényi et al. 1968) referred some brachiopods and a Subastieria sp. from the nearby Dezsô Rezső Valley, and considered its age late Valanginian. No picture, description or repository data are available of this record; therefore, it is not included in this study. Bujtor (2013) reported previously unknown ammonite species of loose blocks from the floor of Hidasi Valley (Olcostephanus guebhardi, Neocomites (Eristavites) teschenensis, $N$. (E.) platycostatus) representing younger, but still early Valanginian age. Bujtor et al. (2013) investigated the belemnite and calcareous dinoflagellate fauna of the Zengóvárkony SHV and concluded that the fauna represents the upper Valanginian Criosarasinella furcillata and the lower Hauterivian Acanthodiscus radiatus Zones. Some poorly preserved haploceratid, and phylloceratid ammonites are reported from the locality, and a Lytoceras subfimbriatum (Bujtor 2012), however, these ammonites are not 
Fig. 1 Locality map and lithostratigraphic subdivision of the Lower Cretaceoues (pars) strata mentioned in the text. a Lithostratigraphy of the Mecsek tectonic zone for the study period. Numerical ages after Cohen et al. (2013). b Simplified map of Hungary. Black rectangle indicates the study area. c The Hidasi Valley area and the locality. Abbreviations: $A L F$ Apátvarasd limestone Fm, $H M F$ Hidasivölgy Marl Fm, $M B F$ Mecsekjánosi Basalt Fm, $M C F$ Magyaregregy Conglomerate Fm, $M L F$ Márévár Limestone Fm. Lithostratigraphic units after Császár (1996), simplified

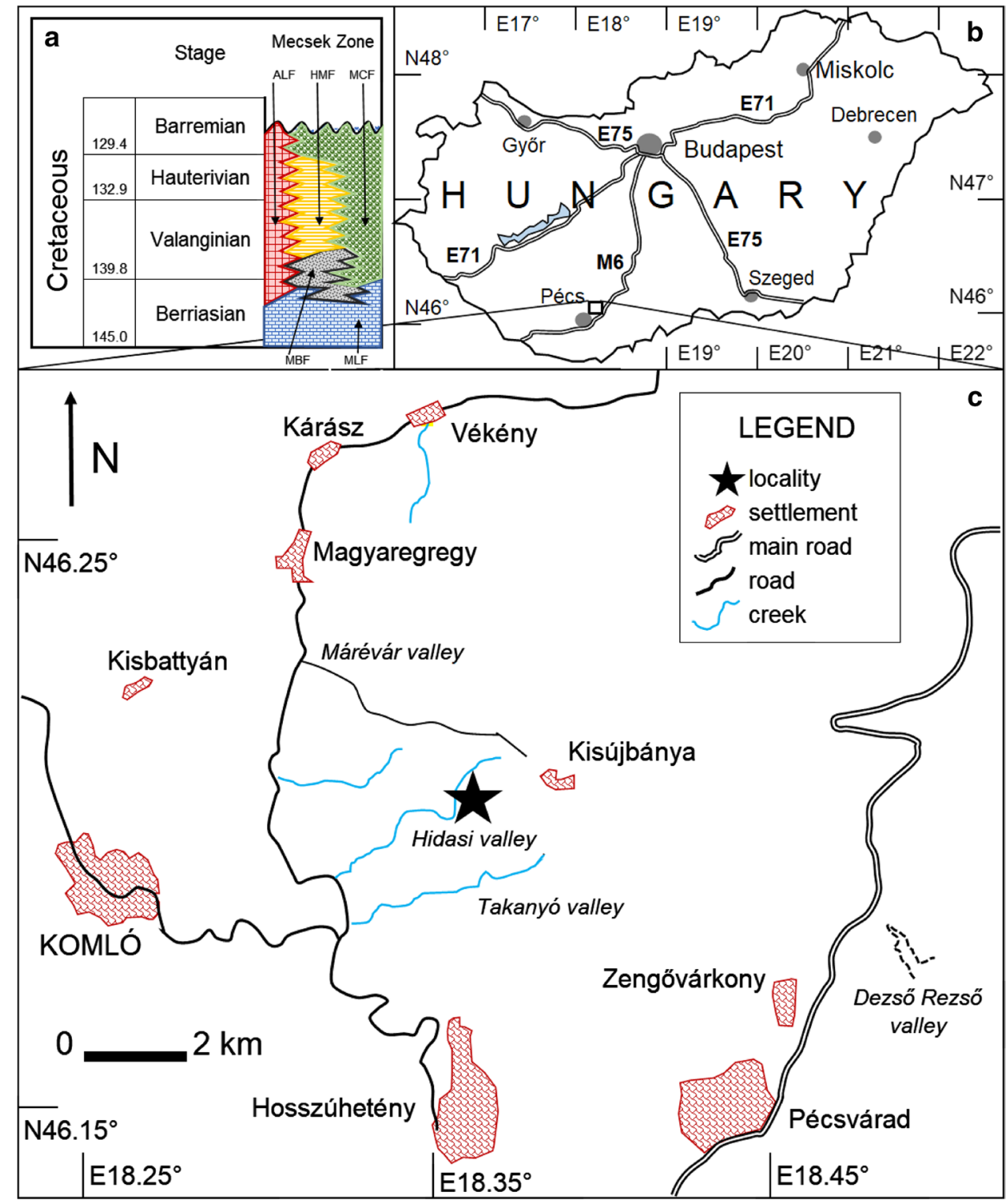

decisive for the late Valanginian or the early Hauterivian. These are the only Hauterivian ammonites known from the Mecsek Mountains. Other Lower Cretaceous localities in the study area did not provide assignable ammonites. The aim of the paper is to describe the first late Valanginian ammonite from the Mecsek Mountains.

\section{Geological setting}

The Mecsek Mountains is a surface appearance of the Mecsek tectonic zone, which is the northernmost unit of the Tisza mega-unit (Haas and Péró 2004), that is considered a microplate (Csontos and Vörös 2004). Cretaceous development of the Mecsek Mountains is characterised by a calm hemipelagic sedimentation of Marls and Limestones that was interrupted by volcanic activity that built up a volcanic edifice during the late Berriasian-Valanginian. The volcanic activity is considered a by-product of intra-plate rifting (Embey-Isztin 1981). Erosion of the emerged volcanic basement produced various clastic sediments deposited on the submarine slopes of the volcanic edifice: Magyaregregy Conglomerate, Hidasivölgy Marl and Apátvarasd Limestone Formations. By the end of the Valanginian, the volcanic activity ceased in the Mecsek Mountains and from the Hauterivian onward limestone sedimentation continued again. In other parts of the Mecsek tectonic zone, $150 \mathrm{~km}$ in NE direction from the Mecsek Mountains, younger volcanites are reported from cores drilled on the Great Hungarian Plain (Bércziné Makk et al. 1996) that probably have an Albian age. However, the youngest Lower Cretaceous sediments in the Mecsek Mountains are thought to be not 
younger than mid-Barremian (Kázmér 1986; Balla and Bodrogi 1993; Császár and Turnšek 1996).

Kázmér (1986: fig. 14) synthesised the previous data and concluded that there were continuous Jurassic-Cretaceous sedimentation in the Mecsek Mountains; however, sediments younger than mid-Barremian strata are not exposed on the surface due to erosion. Later synthesis of Császár et al. (2000: 697, fig. 1) supposed a continuous sedimentation till the Turonian. Hypothesis on multiple volcanic activities and continuous Early Cretaceous sedimentation in the Mecsek Mountains is based on evidence from boreholes drilled on the Great Hungarian Plain (Bércziné Makk et al. 1996) and the presence of a Turonian pelagic marl (= Vékény Marl) in the Mecsek Mountains (Balla and Bodrogi 1993). These indications are based on micropaleontological and radiometric data, therefore, not useful to trace younger Cretaceous ammonite-bearing strata in the Mecsek Mountains. Ammonites from the Mecsek Mountains indicate only early Valanginian age so far.

To report any younger (late Valanginian, Hauterivian or even younger) ammonites from the Mecsek Mountains, therefore, important to decide the ambiguous presence of younger Cretaceous strata. Császár and Turnšek (1996) and Császár (2002) reported reef-building corals, stromatoporoids and coralline algae collected mainly from the Kisbattyán locality (Fig. 1); some of them indicate puzzling ages: Mesomorpha ornata Morycowa, and Heliocoenia rarauensis Morycowa refer to Aptian; Dimorphastraeopsis patellaris (Stoliczka), Latiastraea mucronata Siharulidze, and Myriophyllia propria Siharulidze refer to Albian. These fossils came from rock samples collected from scree and debris in three localities (Kisbattyán, Márévár valley, and Kisújbánya) and determined from thin sections. Although some poorly preserved ammonites were reported together with these fossils but being impossible to assign any genera/ species. These confusing ages created an enigma regarding the age of the youngest Cretaceous strata in the Mecsek Mountains and contradicting the widely admitted middle Barremian age. Therefore, any ammonite record, that justifies younger ages than early Valanginian can help to solve this unassured situation of the Cretaceous stratigraphy of the Mecsek Mountains.

\section{Locality details}

The locality is situated in a branch-ravine of the upper part of the Hidasi Valley, eastern Mecsek Mountains, Hungary (Fig. 1). The coordinates of the locality are $46.2047^{\circ}$ North latitude, $18.3451^{\circ}$ East longitude. This part of the valley is traversing the hemipelagic Lower Cretaceous (Berriasian to Valanginian) variegated Marl-Limestone sequence of the Hidasivölgy Marl Fm. (for details see Bujtor 1993). The herein described ammonite specimen is a fairly preserved individual being collected by the second author (G.G.) from scree of a small branch-ravine of the Hidasi Valley, therefore, its exact stratigraphic position is not known. The source rock of the ammonite is a massive limestone bed and it probably came from the variegated Marl-Limestone beds representing the Valanginian or younger ages. Considering the possible original position of the ammonite in the Hidasi Valley, it is supposed that younger (Hauterivian) strata may be also present.

\section{Materials and methods}

The figured and measured specimen was collected by the second author (G.G.) in June 2020. The given dimensions are in $\mathrm{mm}$ and acquired by a manual caliper. The picture is taken by a Nikon D3500 DSLR camera and it is digitally improved. The applied ammonite zonation follows the standard ammonite zonation for the Mediterranean Province of the Tethyan Faunal Realm of Reboulet et al. (2018). Abbreviations: Fm: Formation; D: diameter of the conch; $\mathrm{Wb}$ : whorl height; Wb: whorl breadth; $\mathrm{U}$ : diameter of umbilicus; SHV: sediment hosted vent (sensu Bell et al. 2016); Ma: million years; n.d.: no data available due to the poor preservation.

\section{Systematic palaeontology}

Repositories and institutional abbreviations. The figured specimen included in this study is deposited in the palaeontological collection of the Mining and Geological Survey of Hungary, Budapest (MBFSz) under prefix ' $\mathrm{K}$ '.

Phylum Mollusca Linnaeus, 1758

Class Cephalopoda Cuvier, 1795

Order Ammonoidea Zittel, 1884

Suborder Ammonitina Hyatt, 1889

Superfamily Perisphinctoidea Steinmann, 1890

Family Neocomitidae Salfeld, 1921

Subfamily Neocomitinae Salfeld, 1921

Genus Tescheniceras Vašíček, 2020

Type species. Neocomites (Teschenites) flucticulus Thieuloy, 1977.

Tescheniceras subpachydicranum (Reboulet 1996)

Figure 2

1996 Teschenites subpachydicranus $\mathrm{n}$. sp.-Reboulet: 112, pl. 11, figs. 1-7; pl. 12, figs. 2, 4, 6; pl. 13, fig. 8 . 


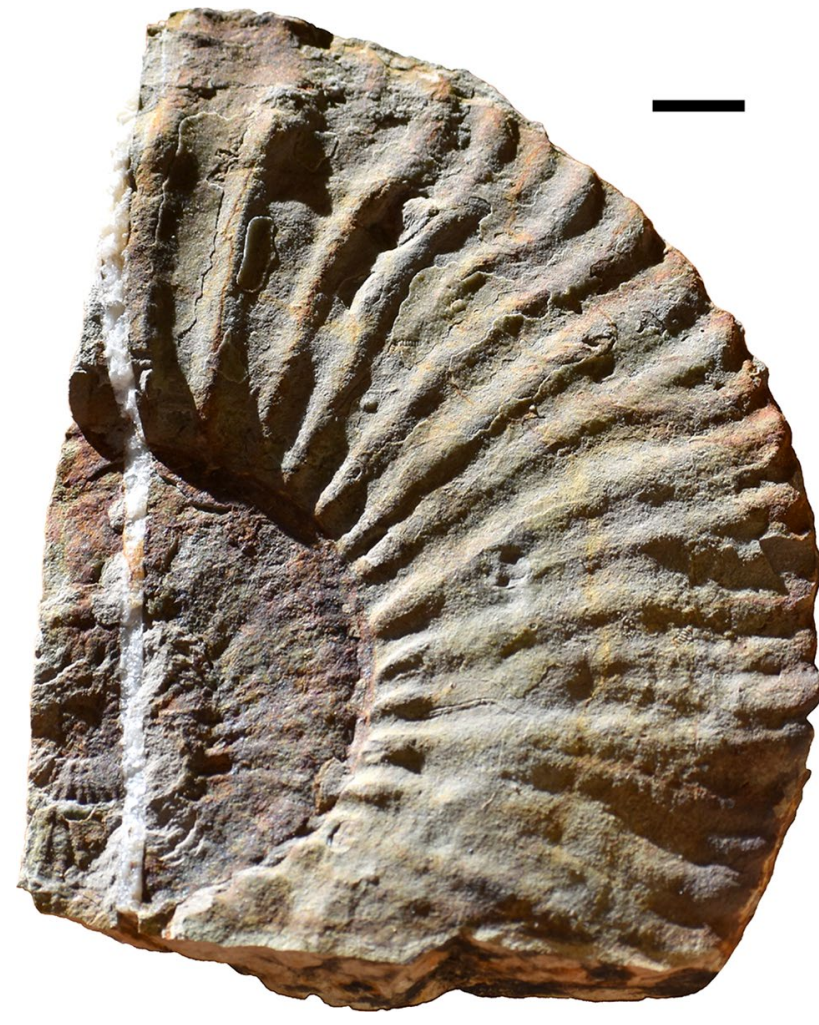

Fig. 2 Tescheniceras subpachydicranum (Reboulet, 1996). Lateral view of specimen K 2020.2.1 from the Hidasi Valley, Hidasivölgy Marl Fm. Scale bar indicates $1 \mathrm{~cm}$

non 1996 Teschenites aff. subpachydicranus n. sp.Reboulet: 116, pl. 14, fig. 22.

2005 Neocomites (Teschenites) subpachydicranus (Reboulet)—Klein: 320 (cum syn.).

2009 Neocomites subpachydicranus (Reboulet)—Főzy and Janssen: fig. 3k.

2018 N. subpachydicranus -Aguado et al.: 128, fig. 5f.

2020 Tescheniceras subpachydicranum (Reboulet)— Vašíček: 11, text-fig. $3 b$.

Material. One fairly preserved, deformed and fragmentary internal mould (K 2020.2.1) from the scree of a branch-ravine.

\section{Dimensions.}

\begin{tabular}{lccccccc}
\hline Specimen & D & Wb & Wh & U & Wb/Wh & Wh/D & U/D \\
\hline K 2020.2.1 & n.d & n.d & 49 & 50 & n.d & n.d & n.d
\end{tabular}

Description. It is a fairly preserved and flattened internal mould of a fragmentary, large macroconchiate specimen. Five whorls are seen. The umbilicus is wide and shallow. Due to the flattened status, neither the umbilical nor the ventral shoulders seen. The cross section is not seen. The early whorls $(D=15 \mathrm{~mm})$ present simple, radial ribs that sometimes bifurcate at the umbilical margin. The innermost visible whorls show rather stronger and relatively sparsely distributed ribs that raise from the umbilical tubercles. Two ribs raise from a tubercle. The middle whorls $(D=50 \mathrm{~mm})$ are barely seen; at the umbilical margin some tubercles rise. The last whorl (above $\mathrm{D}=100 \mathrm{~mm}$ ) bears prorsiradiate and fine tubercles. The primary ribs are wide, short, widely placed and developed from the umbilical tubercles/clavi. The primaries travel straightforward on the lower flank, become slightly rectiradiate above the midflank; close to the venter primaries bend forward. On the last quarter of the ultimate whorl, 11 primaries rise at the umbilical shoulder, and 19 ribs cross the venter. Bifurcation of the primaries are not regular. If the primaries bifurcate, then the ribs become falcoid on the upper flank. Rarely, intercalatory ribs may appear slightly below the midflank. The single main ribs bear fine tubercles on the upper flank. No constrictions, aperture, or suture are preserved.

Remarks. Although the holotype of this species is a microconch specimen (FSL 488,832, pl. 11, fig. 6 of Reboulet 1996), but the designated macroconch paratype (FSL 488,878 , pl. 11, fig. 7 of Reboulet 1996) provides the possibility for detailed comparison. The present specimen is considered a macroconch and represents the large, coarsely ribbed stock of the species. The present specimen is most similar to the specimen of FSL 48,878 of Reboulet (1996: pl. 11, fig. 7). Vašíček (2020: fig. 3b) presented a microconch specimen (SNM Z40068) that has a very similar ribbing on its last quarter whorl being similar to the ribbing of the last quarter whorl of our specimen.

The closest species to Tescheniceras subpachydicranum is Tescheniceras pachydicranum (Thieuloy, 1977) from which Reboulet (1996) separated this species as the variant A of Teschenites pachydicranus (Thieuloy, 1977). These species have very similar ribbing on the early whorls, however, on later stages, the latter one develops finer and fainter ribbing on the last whorl. When Vašíček (2020: 573) introduced the new genus Tescheniceras, he clearly stated that "Teschenites could be considered as a synonym of the genus Neocomites. However, I prefer to restrict the use of Neocomites only for neocomitids from around the Lower/Upper Valanginian boundary, and to use Tescheniceras gen. nov. for neocomitids around the Valanginian/Hauterivian boundary." This view is accepted and followed here.

Stratigraphic and geographic distribution. The stratigraphic distribution of Tescheniceras subpachydicranum is quite wide (overlapping three ammonite zones) and varies by localities. Geographically, it is reported from the Western Tethys both northern and southern margin: Fózy and Janssen (2009) reported it from the Neocomites peregrinus Zone of the Gerecse Mountains, Hungary; Aguado et al. (2018) 
described it from the Nicklesi Subzone of the N. peregrinus Zone of Cehegín (Subbetic domain, SE Spain). Vašíček (2005: fig. 2, however, only for $T$. ex gr. pachydicranus) reports from the Upper Valanginian Criosarasinella furcillata Zone of the Western Carpathians, Slovakia. Mutterlose et al. (2020) reported it from the uppermost Valanginian of La Charce, SE France. Wippich (2003) reported it from the base of the Hauterivian of the Atlas Mountains, Morocco. According to Vašíček (2020: 579), it is characteristic for the uppermost Valanginian.

\section{Stratigraphic and other consequences}

All occurrences of Tescheniceras subpachydicranum (Reboulet, 1995) from the northern margin of the western Tethys (Spain, France, Slovakia) refer to the latest Valanginian Criosarasinella furcillata Zone (except for an older record from the Gerecse Mountains reported by Főzy and Janssen (2009)). The only younger record is reported from Morocco (Wippich 2003) and represents the earliest Hauterivian. We may conclude, therefore, that the Tescheniceras subpachydicranum from the upper part of the Hidasi Valley refer to the Furcillata Zone. In the Kisújbánya Basin (including the Hidasi Valley), only a discontinuous lower Valanginian sequence known (Bujtor 1993) with a tentative presence of the upper Valanginian Verrucosum Zone. The presence of the upper Valanginian ammonite Tescheniceras subpachydicranum indicates that discontinuity in the sedimentation is probably only due to the sampling bias and further comprehensive collection may cover up the discontinuity. However, it is noteworthy that there is a limited chance for any comprehensive field work, because the study area is a highly protected national reserve (Natura 2000 area).

This record is also important from another point of view. In the nearby Dezső Rezső Valley, a unique, SHV-type paleoenvironment is reported (Bujtor et al. 2013; Bujtor and Szinger 2018) from the same age indicating that these environments were heteropic facies. The Hidasi Valley represents the hemipelagic basinal, and the SHV refers to the shallow marine facies.

\section{Conclusions}

The discovery of the late Valanginian ammonite Tescheniceras subpachydicranum (Reboulet, 1996) from the Hidasi Valley (Kisújbánya Basin, eastern Mecsek Mountains) is the first ammonite-supported evidence for the presence of upper Valanginian strata (Criosarasinella furcillata Zone) in the Mecsek Mountains. This record on one hand implies a continuous Valanginian sedimentation in the Kisújbánya Basin and justifies that the discontinuous sequence is apparent and caused by the sampling bias. On the other hand, this record refers to the fact that the Kisújbánya Basin (including the Hidasi Valley) were the hemipelagic basin, where calm sedimentation took place but in the nearby, elevated and shallow marine SHV environment active hydrothermal venting occurred.

Acknowledgements Open access funding provided by the University of Pécs (PTE). We are indebted to László Makádi (MBFSz) for deposition our material in the palaeontological collection of the MBFSz, Budapest. Our special thanks due to Zdenek Vašíček and Vladan Radulović for the thorough discussion of the taxonomic position of our specimen pointing to the crucial taxonomic features. Our special thanks due to the reviewers, especially Camille Frau and an anonymous reviewer, the editors Christian Klug and Mike Reich for their detailed critical remarks and suggestions as well as correcting our English that significantly improved the quality of this paper. Special thanks are due to the Biodiversity Heritage Library for free access to old publications.

Funding Open access funding provided by University of Pécs.

Open Access This article is licensed under a Creative Commons Attribution 4.0 International License, which permits use, sharing, adaptation, distribution and reproduction in any medium or format, as long as you give appropriate credit to the original author(s) and the source, provide a link to the Creative Commons licence, and indicate if changes were made. The images or other third party material in this article are included in the article's Creative Commons licence, unless indicated otherwise in a credit line to the material. If material is not included in the article's Creative Commons licence and your intended use is not permitted by statutory regulation or exceeds the permitted use, you will need to obtain permission directly from the copyright holder. To view a copy of this licence, visit http://creativecommons.org/licenses/by/4.0/.

\section{References}

Aguado, R., M. Company, J.M. Castro, G.A. de Gea, J.M. Molina, L.M. Nieto, and P.A. Ruiz-Ortiz. 2018. A new record of the Weissert episode from the Valanginian succession of Cehegín (Subbetic, SE Spain): Bio- and carbon isotope stratigraphy. Cretaceous Research 92: 122-137. https://doi.org/10.1016/j.cretres.2018.07. 010.

Balla, Z., and I. Bodrogi. 1993. The 'Vékény Marl' Formation of Hungary. Cretaceous Research 14: 431-448. https://doi.org/10.1006/ cres.1993.1030.

Bell, J.B., C. Woulds, L.E. Brown, C.J. Sweeting, W.D.K. Reid, C.T.S. Little, and A.G. Glover. 2016. Macrofaunal Ecology of Sedimented Hydrothermal Vents in the Bransfield Strait Antarctica. Frontiers in Marine Science 3: 32. https://doi.org/10.3389/fmars. 2016.00032.

Bércziné Makk, A., G. Császár, and A. Nusszer. 1996. Stratigraphy and geological evolution of the Mesozoic basement of the Mecsek Zone in the Central Part of the Great Hungarian Plain (EastCentral Hungary). Földtani Közlöny 126: 185-207.

Bujtor, L. 1993. Valanginian ammonite fauna from the Kisújbánya Basin (Mecsek Mts., South Hungary) and its palaeobiogeographical significance. Neues Jahrbuch für Geologie und Paläontologie, Abhandlungen 188: 103-131.

Bujtor, L. 2012. The palaeontological character of the Lower Cretaceous (Valanginian) hydrothermal vent site of the Mecsek Mts Hungary. Földtani Közlöny 142: 137-148. 
Bujtor, L. 2013. Valanginian perisphinctid ammonites from the Kisújbánya Basin (Eastern MecsekMts., Hungary). Cretaceous Research 41: 1-16. https://doi.org/10.1016/j.cretres.2012.10.001.

Bujtor, L., and B. Szinger. 2018. Micropaleontological observations on the Lower Cretaceous iron ore-related formations of the Mecsek Mts. (Upper Valanginian - Lower Hauterivian, South Hungary). Central European Geology 61: 136-159. https://doi.org/10.1556/ 24.61.2018.08

Bujtor, L., N.N.M. Janssen, and R.M.C.H. Verreussel. 2013. Early Cretaceous (Valanginian and Hauterivian) belemnites and organicwalled dinoflagellate cysts from a marine hydrothermal vent site and adjacent facies of the Mecsek Mts., Hungary. Neues Jahrbuch für Geologie und Paläontologie, Abhandlungen 269: 135-148. https://doi.org/10.1127/0077-7749/2013/0341.

Cohen, K.M., S.C. Finney, P.L. Gibbard, and J.-X. Fan. 2013. The ICS International Chronostratigraphic Chart. Episodes 36: 199-204. https://doi.org/10.18814/epiiugs/2013/v36i3/002.

Császár, G., ed. 1996. Magyarország litosztratigráfiai alapegységei. Kréta. Budapest: Magyar Állami Földtani Intézet.

Császár, G. 2002. Urgon formations in Hungary with special reference to the Eastern Alps, the Western Carpathians and the Apuseni Mountains. Geologica Hungarica series Geologica 25: 1-209.

Császár, G., and D. Turnšek. 1996. Vestiges of atoll-like formations in the Lower Cretaceous of the Mecsek Mountains, Hungary. Cretaceous Research 17: 419-442. https://doi.org/10.1006/cres. 1996.0026

Császár, G., K. Kollányi, M. Lantos, and Gy. Lelkes, and E. Tardiné Filácz. 2000. The age and sedimentary environment of the Hidasivölgy Marl Formation. Földtani Közlöny 130: 695-723.

Csontos, L., and A. Vörös. 2004. Mesozoic plate tectonic reconstruction of the Carpathian region. Palaeogeography, Palaeoclimatology, Palaeoecology 210: 1-56. https://doi.org/10.1016/j.palaeo. 2004.02.033.

Cuvier, G. 1795. Second Mémoire sur l'organisation et les rapports des animaux à sang blanc, dans lequel on traite de la structure des Mollusques et de leur division en ordre, lu à la Société d'Histoire Naturelle de Paris, le 11 Prairial an troisième. Magazin Encyclopédique, ou Journal des Sciences, des Lettres et des Arts 2: 433-449.

Embey-Isztin, A. 1981. Statistical analysis of major element patterns in basic rocks of Hungary: An approach to determine their tectonic settings. Földtani Közlöny 111: 43-58.

Főzy, I., and N.N.M. Janssen. 2009. Integrated Lower Cretaceous biostratigraphy of the Bersek Quarry, Gerecse Mountains, Transdanubian Range, Hungary. Cretaceous Research 30: 78-92. https://doi.org/10.1016/j.cretres.2008.05.002.

Haas, J., and Cs. Péró. 2004. Mesozoic evolution of the Tisza Megaunit. International Journal of Earth Sciences 93: 297-313. https:// doi.org/10.1007/s00531-004-0384-9.

Hetényi, R., G. Hámor, and I. Nagy. 1968. Magyarázó a Mecsek hegység földtani térképéhez 10 000-es sorozat. Magyar Állami Földtani Intézet, Budapest: Apátvarasd.

Hofmann, K. 1907. Geologische Mitteilungen über das Pécser Gebirge. Földtani Közlöny 37: 161-167.

Hofmann, K., and E. Vadász. 1912. A Mecsekhegység középsöneokom rétegeinek kagylói. Jahrbuch der königlichen ungarischen Geologischen Anstalt 20: 189-226.

Horváth, A. 1968. Beobachtungen in den Unterkreide-Schichten des Mecsek-Gebirges. Földtani Közlöny 98: 241-247.

Hyatt, A. 1889. Genesis of the Arietidae. Smithsonian Contributions to Knowledge 26: 1-238.
Kázmér, M. 1986. Tectonic units of Hungary: their boundaries and stratigraphy (a bibliographic guide). Annales Universitatis Scientiarum Budapestinensis de Rolando Eötvös nominatae section Geologica 26: 45-120.

Klein, J. 2005. Lower Cretaceous Ammonites I - Perisphinctaceae 1, Himalayitidae, Olcostephanidae, Holcodiscidae, Neocomitidae, Oosterellidae. Fossilium Catalogus (I: Animalia) 139: 1-484, Backhuys Publishers, Leiden.

Linnaeus, C. 1758. Systema Naturae, Editio X, 1-824, Holmiae: Laurentii Salvi.

Mutterlose, J., P.F. Rawson, and S. Reboulet. 2020. The Global Boundary Stratotype Section and Point (GSSP) for the base of the Hauterivian Stage (Lower Cretaceous), La Charce, southeast France. Episodes. https://doi.org/10.18814/epiiugs/2020/020072.

Reboulet, S. 1996. L'Évolution des ammonites du ValanginienHauterivien inférieur du Bassin Vocontien et de la plate-forme Provençale (Sud-Est de la France): Relations avec la stratigraphie séquentielle et implications biostratigraphiques. Documents des Laboratoires de Géologie Lyon 137[for 1995]: 1-371.

Reboulet, S., O. Szives, B. Aguirre-Urreta, R. Barragán, M. Company, C. Frau, M.V. Kakabadze, J. Klein, J.A. Moreno-Bedmar, A. Lukeneder, A. Pictet, I. Ploch, S.N. Raisossadat, Z. Vašíček, E.J. Baraboshkin, and V.V. Mitta. 2018. Report on the 6th International Meeting of the IUGS Lower Cretaceous Ammonite Working Group, the Kilian Group (Vienna, Austria, 20 ${ }^{\text {th }}$ August 2017). Cretaceous Research 91: 100-110. https://doi.org/10.1016/j.cretr es.2018.05.008.

Salfeld, H. 1921. Kiel- und Furchenbildung auf der Schalenaussenseite der Ammonoideen in ihrer Bedeutung für die Systematik und Festlegung von Biozonen. Zentralblatt für Mineralogie, Geologie und Paläontologie 1921: 343-347.

Steinmann, G. 1890. Elemente der Paläontologie. Leipzig: W. Engelmann.

Thieuloy, J.-P. 1977. La zone à callidiscus du Valanginien supériur vocontien (Sud-Est de la France). Lithostratigraphie, ammonitofaune, limite Valanginien-Hauterivien, correlations. Géologie Alpine 53: 83-143.

Vadász, M.E. 1914. A Zengövonulat és a környező dombvidék földtani viszonyai. Jahresberichte königlichen ungarischen Geologischen Anstalt 1913: 336-352.

Vadász, E. 1935. Das Mecsek-Gebirge. Geologische Beschreibung Ungarischer Landschaften I, xxv + 1-180. Budapest: Königlich Ungarische Geologische Anstalt.

Vašíček, Z. 2005. The oldest (Late Valanginian) Crioceratitinae (heteromorphic ammonoids) from the Central Western Carpathians (Slovakia). Geologica Carpathica 56: 245-254.

Vašíček, Z. 2020. Tescheniceras gen. nov. (Ammonoidea) and the definition of the Valanginian/Hauterivian boundary in Butkov Quarry (Central Western Carpathians, Slovakia). Acta Geologica Polonica 70: 569-584. https://doi.org/10.24425/agp.2020.132260.

Wippich, M.G.E. 2003. Valanginian (Early Cretaceous) ammonite faunas from the western High Atlas, Morocco, and the recognition of western Mediterranean 'standard' zones. Cretaceous Research 24: 357-374. https://doi.org/10.1016/S0195-6671(03)00049-1.

Zittel, K.A. 1881 - 1885. Handbuch der Palaeontologie, 1. Abtheilung: Palaeozoologie, Band 2: Mollusca und Arthropoda, 1-823, München \& Leipzig: Oldenbour. 